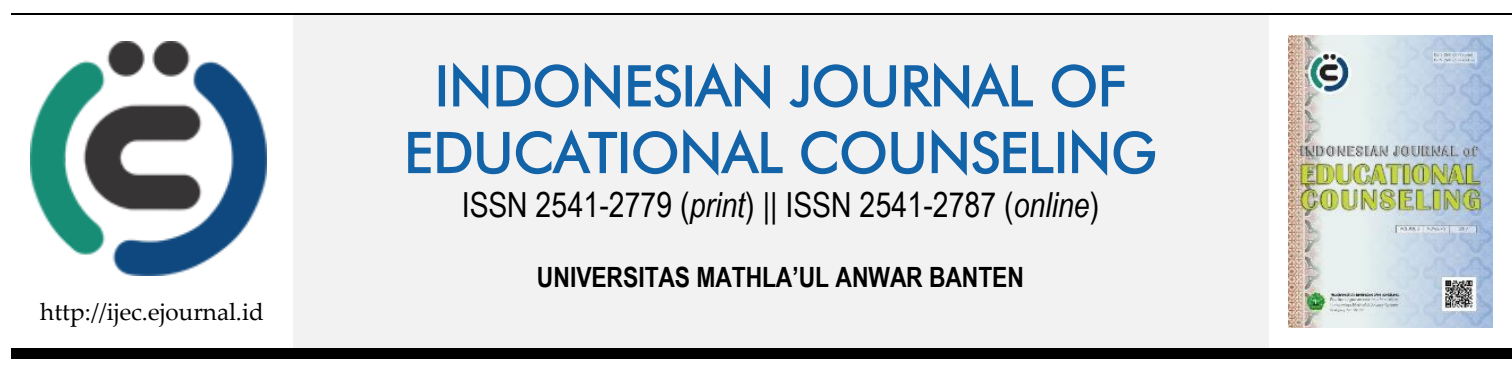

Research Based Article

\title{
Keefektifan Konseling Kelompok Cognitive behavior untuk Meningkatkan Konsep Diri Positif Siswa SMP
}

\author{
Rias Wulan Mustiani ${ }^{1}$ \\ ${ }^{1}$ SMP Negeri 1 Kutorejo, Mojokerto
}

\begin{tabular}{|c|c|}
\hline Article History & ABSTRACT \\
\hline \multirow[t]{2}{*}{$\begin{array}{l}\text { Received: } 09.02 .2019 \\
\text { Received in revised form: } \\
25.04 .2019 \\
\text { Accepted: } 02.07 .2019 \\
\text { Available online: } 23.07 .2019\end{array}$} & $\begin{array}{l}\text { EFFECTIVENESS OF COGNITIVE BEHAVIOR COUNSELING GROUP TO } \\
\text { INCREASE THE POSITIVE SELF CONCEPT OF MIDDLE SCHOOL } \\
\text { STUDENTS. This study aims to test the effectiveness of counseling cognitive } \\
\text { behavior group to improve the positive self-concept of students in junior high. } \\
\text { This research uses a pre-experimental pretest type posttest one-group design. } \\
\text { The data analysis used is paired test of T-test, to see the change of positive self- } \\
\text { concept level in the experimental group between pretest and posttest by looking } \\
\text { at } t \text {-table price at degrees of freedom ( }(\mathrm{dk}) \text {, that is the magnitude is N-1, } \\
\text { significant } \alpha=0,05 \text { ( } 95 \% \text { ) then got } \mathrm{t} \text {-table. }=1.782 \text { assuming if } \mathrm{t} \text { count }>\mathrm{t} \text {-table } \\
\text { then Ha "received." The results of data analysis of the responses of respondents } \\
\text { about positive self-concept show positive self-concept students before } \\
\text { intervention is in the category of being, and there is still a low category of } 13 \\
\text { respondents. As for after the treatment, based on the posttest results, indicate } \\
\text { the criteria of self-concept positive students, no one is in a low category. From } \\
\text { the test result using T-Test, it is proved that counseling group of cognitive } \\
\text { behavior is effective to improve the positive self-concept of junior high school } \\
\text { students, because the value of } t \text { count } t \text { table ( } 7.597>1.782 \text { ), then the hypothesis } \\
\text { that the writer proposed in the form of alternative hypothesis (Ha) the } \\
\text { effectiveness of counseling cognitive behavior group to improve the positive } \\
\text { self-concept of junior high school students, Ha "accepted". }\end{array}$ \\
\hline & $\begin{array}{l}\text { KEYWORDS: Guidance and Counseling Teachers, Pedagogic Competence, } \\
\text { Professional Competence. }\end{array}$ \\
\hline
\end{tabular}

DOI: $10.30653 / 001.201932 .83$

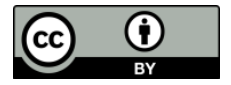

This is an open access article distributed under the terms of the Creative Common Attribution 4.0 International License, which permits unrestricted use, distribution, and reproduction in any medium, provided the original work is properly cited. ○) 2019 Rias Wulan Mustiani.

\section{PENDAHULUAN}

Dewasa ini masa remaja merupakan masa yang menarik untuk diperhatikan karena pada masa ini remaja dihadapkan pada berbagai tantangan dan masalah, baik itu masalah perkembangan maupun masalah lingkungan, peran remaja yang penting dalam kelangsungan hidup di Indonesia telah mendudukkan remaja sebagai salah satu sumber inspirasi yang terus digali dan dipelajari aspek kehidupannya (Mulyana, 2011). 
Pernyataan tersebut dipertegas oleh Habsy (2017a) yang menyatakan bahwa masa remaja merupakan tahapan dari siklus kehidupan yang banyak dibahas oleh para peneliti di bidang bimbingan dan konseling dan psikologi, sebab banyak hal menarik yang dapat ditelaah, hal ini tidak terlepas dari berbagai karakteristik yang khas yang menyertai pertumbuhan dan perkembangan remaja pada aspek fisik, psikologis, spiritual, intelektual, sosial dan ekonomi.

Masa remaja merupakan masa yang penuh pergolakan psikis, emosi dan ketidakseimbangan (Rogers \& Creed, 2011). Pada masa ini seorang individu dihadapkan pada tugas-tugas perkembangan yang justru seringkali mengakibatkan mereka merasa tertekan dan mengalami krisis dalam memahami konsep dirinya sebagai munculnya pikiran irasional dengan hilangnya status individu dalam kelompok (Habsy, 2018a). Konsep diri merupakan pandangan menyeluruh individu tentang totalitas dari diri sendiri mengenai karakteristik kepribadian, nilai-nilai kehidupan, prinsip kehidupan, moralitas, kelemahan dan segala yang terbentuk dari segala pengalaman dan interaksinya dengan orang lain (Ferrando et al., 2011).

Konsep diri positif penting artinya, karena individu dapat memandang diri dan dunianya, mempengaruhi tidak hanya individu berperilaku, tetapi juga tingkat kepuasan yang diperoleh dalam hidupnya (Armeliza, 2013). Setiap individu pasti memiliki konsep diri, tetapi mereka tidak tahu apakah konsep diri yang dimiliki itu negatif atau positif. Siswa yang memiliki konsep diri positif ia akan memiliki dorongan mandiri lebih baik, ia dapat mengenal serta memahami dirinya sendiri, sehingga dapat berperilaku efektif dalam berbagai situasi.

Setiap individu memiliki konsep diri, baik itu konsep diri positif maupun negatif, hanya derajat atau kadarnya yang berbeda-beda (Rakhmat, 2005). Konsep diri positif memegang aspek penting dalam menentukan dan mengarahkan seluruh perilaku individu, maka sedapat mungkin individu bersangkutan harus mempunyai konsep diri positif. Individu yang memiliki konsep diri positif dalam segala sesuatunya akan menanggapinya secara positif, dapat memahami dan menerima sejumlah fakta yang sangat bermacam-macam tentang dirinya sendiri. Ia akan percaya diri, akan bersikap yakin dalam bertindak dan berperilaku (Putri et al., 2017). Sedangkan individu yang memiliki konsep diri negatif akan menanggapi segala sesuatu dengan pandangan negatif, dengan melindungi konsep dirinya dengan cara mengubah atau menolak informasi baru dari lingkungannya (Pramono, 2013).

Konsep diri positif dalam penelitian ini adalah cara pandang individu secara menyeluruh tentang dirinya, yang meliputi kemampuan yang dimiliki, perasaan yang dialami, kondisi fisik dirinya maupun lingkungan terdekatnya. Untuk mengukur konsep diri positif siswa dalam penelitian ini penulis akan menggunakan alat ukur berupa angket, berdasarkan teori (Wylie, 1974), yang meliputi: (a)Yakin akan kemampuan dalam mengatasi masalah, (b) Merasa setara dengan orang lain, (c) Menerima pujian tanpa rasa malu, (d) Kesadaran akan perasaan dan keinginan orang lain, (e) Mampu memperbaiki aspek kepribadian tidak disenangi masyarakat.

Berdasarkan hasil studi pendahuluan, observasi dan wawancara peneliti yang dilakukan pada tanggal 30 November 2018, ditemukan pada hampir 80 \% siswa SMP di Mojokerto, yang belum mempunyai konsep diri positif gejala yang nampak yaitu membolos, hasil prestasi belajar yang rendah, menyontek, membuat gaduh saat pelajaran, berkelahi, adanya siswa yang melanggar tata tertib sekolah, adanya siswa yang memiliki 
perasaan rendah diri, dan adanya siswa yang mempunyai perasaan tidak mampu melaksanakan tugas, siswa yang demikian itu dapat dikatakan memiliki konsep diri yang negatif.

Pada seting pendidikan upaya konselor sekolah dalam rangka membantu meningkatkan konsep diri positif siswa dengan memberikan layanan konseling. Proses pemahaman konselor terhadap kehidupan konseli dititahkan sebagai kepiawaian konselor untuk menumbuhkan sumber-sumber potensi diri konseli sebagai perwujudan kualitas hidup yang lebih bermakna (Habsy et al., 2017). Konseling dalam lingkup pendidikan merupakan upaya penanganan masalah dalam rangka memfasilitasi perkembangan individu dalam lingkungannya yang tertuju pada upaya menciptakan kondisi optimum bagi perkembangan individu (Habsy, 2017b). Konseling kelompok merupakan salah satu jenis layanan yang tepat dalam memberikan kontribusi pada siswa untuk mengembangkan konsep diri positif (Surya, 2012).

Salah satu pendekatan konseling yang dapat digunakan untuk membantu konseli dalam permasalahan konsep diri positif adalah konseling cognitive behavior. Tujuan konseling kelompok cognitive behavior adalah untuk mengajak konseli menentang pikiran yang negatif dengan menampilkan bukti-bukti yang bertentangan dengan keyakinan mereka tentang masalah yang dihadapi (Sa'adah \& Rahman, 2015). Konseling Kelompok Kognitif Perilaku adalah pendekatan konseling yang diterapkan secara kelompok dengan mengkombinasikan pendekatan kognitif dan perilaku, yang bertujuan untuk mengatasi permasalahan harga diri dengan cara memaksimalkan aktivitas kognitif, untuk menghasilkan perubahan pada pemikiran, emosi, perilaku dan reaksi fisiologis (Habsy, 2014).

Berdasarkan hasil paparan latar belakang di atas, maka rumusan penelitian ini adalah: Apakah konseling kelompok cognitive behavior efektif meningkatkan konsep diri positif siswa SMP? Adapun kerangka konseptual penelitian divisualisasikan dalam Gambar 1.

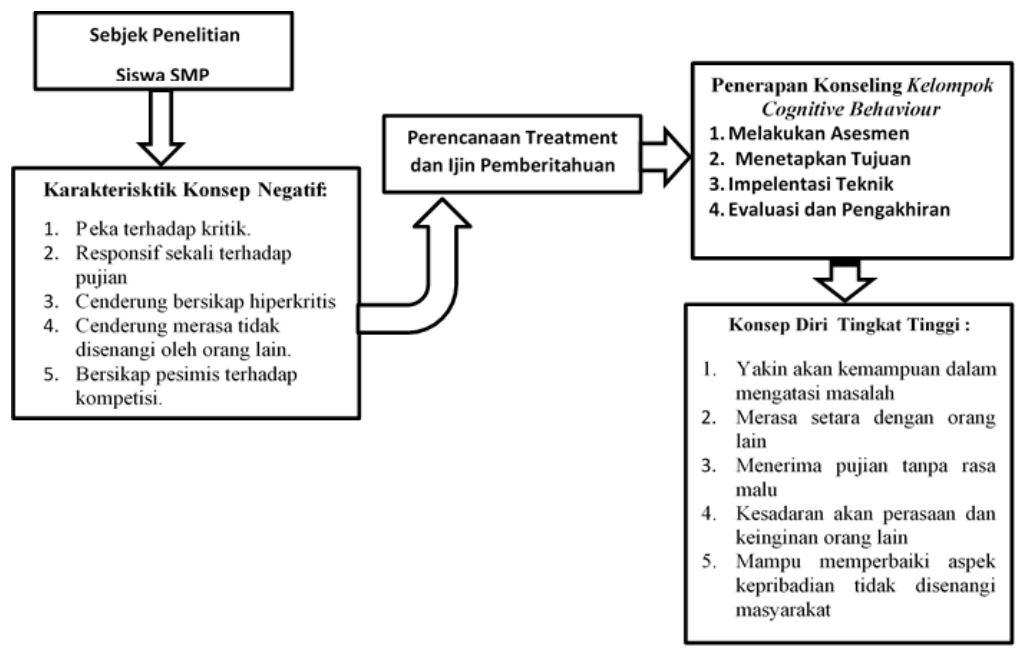

Gambar 1. Kerangka Konseptual Penelitian

\section{METODE}

Desain atau rancangan penelitian merupakan suatu proses yang diperlukan dalam perencanaan dan pelaksanaan sebuah penelitian (Habsy, 2017). Dalam penelitian ini, 
peneliti menggunakan pendekatan kuantitatif dengan rancangan penelitian yang dipakai oleh peneliti adalah rancangan penelitian eksperimen yang berbentuk one group pretestposttest design. Pemahaman konsep diri positif sebagai variabel terikat (dependent variabel) dilambangkan dengan $\mathrm{Y}$, sedangkan konseling kelompok cognitive behavior sebagai variabel bebas (independent variabel). Dalam penelitian ini peneliti menggunakan one group pretest dan posttest desain yang dibuatkan bagan dalam Gambar 2.

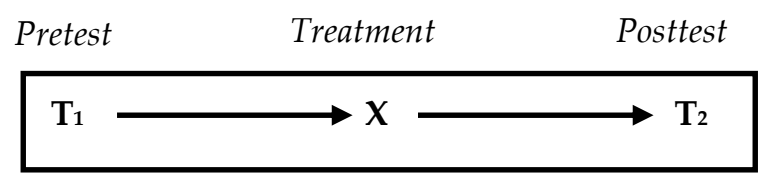

Gambar 2. Rancangan Penelitian

Keterangan:

$\mathrm{T}_{1}$ : pretest, untuk mengukur mean kecemasan mengemukakan pendapat sebelum siswa diberi konseling cognitive behavior

$\mathrm{T}_{2}$ : posttest, untuk mengukur mean kecemasan mengemukakan pendapat sesudah siswa diberi konseling cognitive behavior

$X$ : treatment, yaitu konseling realita

Berdasarkan Gambar 2, dapat diuraikan kegiatan pertama yang dilakukan oleh peneliti adalah melakukan pretest dengan menyebarkan angket konsep diri positif, kemudian subjek dengan hasil inventori konsep diri positif rendah akan diberikan treatment (perlakuan) berupa konseling kelompok cognitive behavior kemudian dari subyek konsep diri positif rendah dilakukan postest dengan angket untuk melakukan pengukuran akhir. Secara visual kerangka kerja konseling kelompok cognitive behavior untuk meingkatkan konsep diri positif siswa SMP, diilustrasikan dalam Gambar 3.

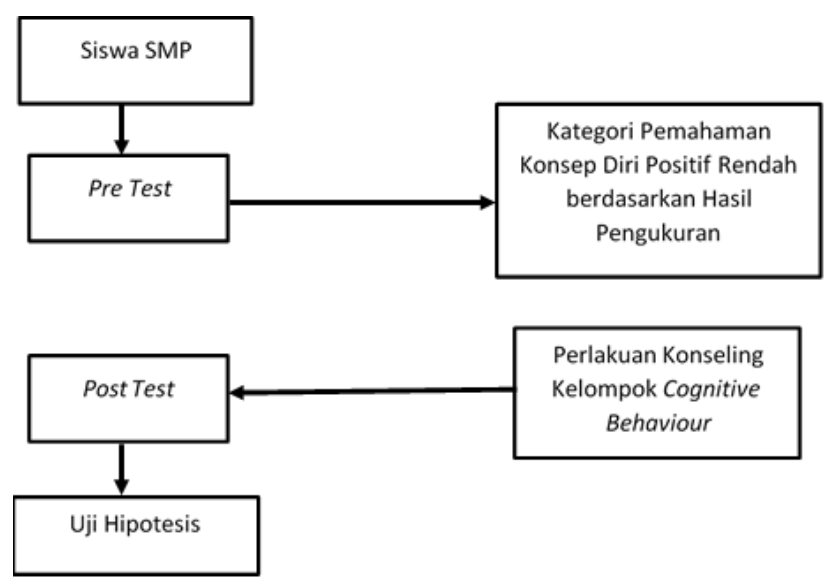

Gambar 3. Kerangka Penelitian

(Diadaptasi dari Habsy, 2018)

\section{Populasi Penelitian}

Populasi dalam penelitian ini adalah siswa kelas VII A-B SMP Negeri 1 Kutorejo, yang berjumlah 66 siswa. Untuk lebih jelasnya tentang populasi penelitian ini, bisa dilihat pada Tabel 1 . 
Tabel 1. Populasi Penelitian

\begin{tabular}{lllll}
\hline No & Kelas & Laki-laki & Perempuan & Jumlah \\
\hline 1 & VII-A & 13 & 20 & 33 \\
\hline 2 & VII-B & 19 & 14 & 33 \\
\hline & Jumlah & 32 & 34 & 66 \\
\hline
\end{tabular}

Dari populasi tersebut,di atas dipilih beberapa siswa untuk menjadi subjek penelitian sebagai kelompok eksperimen, dimana pengambilan sampel berdasarkan, data siswa yang mengalami konsep diri positif rendah pada pengukuran inventori. Pemilihan subjek penelitian ditentukan berdasarkan pemenuhan kriteria-kriteria tertentu sebagai berikut:

1) Tercatat sebagai siswa SMP Negeri 1 Kutorejo, pada tahun ajaran 2018/2019.

2) Teridentifikasi sebagai siswa dengan konsep diri negatif berdasarkan alat ukur inventori yang digunakan dalam penelitian ini.

3) Bersedia mengikuti seluruh kegiatan intervensi yang dilakukan peneliti dan mengisi lembar persetujuan yang disediakan oleh peneliti.

\section{Instrumen Penelitian}

Dalam proses pengumpulan data diperlukan alat atau instrument pengumpulan data yang benar-benar dapat mengumpulkan data dengan baik. Dalam penelitian ini terdapat dua variabel yaitu konseling kelompok cognitive behavior yang difungsikan sebagai variabel terikat dan konsep diri positif yang difungsikan sebagai variabel bebas. Adapun instrumen yang dipakai dalam penelitian ini berupa angket atau kuesioner.

Tabel 2. Kisi-kisi Angket

\begin{tabular}{|c|c|c|c|c|c|}
\hline \multirow[t]{2}{*}{ Variabel } & \multirow[t]{2}{*}{ Indikator } & \multirow[t]{2}{*}{ Deskriptor } & \multicolumn{2}{|c|}{ Item } & \multirow{2}{*}{$\begin{array}{c}\text { Jumlah } \\
\text { Item }\end{array}$} \\
\hline & & & + & - & \\
\hline \multirow{15}{*}{$\begin{array}{l}\text { Konsep } \\
\text { Diri }\end{array}$} & \multirow{4}{*}{$\begin{array}{l}\text { Yakin akan kemampuan } \\
\text { dalam mengatasi } \\
\text { masalah }\end{array}$} & Mandiri & 1,2 & 21 & \multirow[t]{4}{*}{7} \\
\hline & & Ketenangan & 11 & 22 & \\
\hline & & $\begin{array}{l}\text { Kesanggupan menerima } \\
\text { tugas }\end{array}$ & 12 & & \\
\hline & & $\begin{array}{l}\text { Mengembangkan bakat dan } \\
\text { potensi }\end{array}$ & 4 & 24 & \\
\hline & \multirow{3}{*}{$\begin{array}{l}\text { Merasa setara dengan } \\
\text { orang lain }\end{array}$} & Sikap menghargai & 5,16 & 25, & \multirow[t]{3}{*}{7} \\
\hline & & Senang bergaul & 6, & 26 & \\
\hline & & Senang bekerja sama & 15 & & \\
\hline & \multirow{2}{*}{$\begin{array}{l}\text { Menerima pujian tanpa } \\
\text { rasa malu }\end{array}$} & Bersikap wajar & 9,19 & & \multirow[t]{2}{*}{3} \\
\hline & & Bersikap sportif & & 20 & \\
\hline & \multirow{2}{*}{$\begin{array}{l}\text { Kesadaran akan } \\
\text { perasaan dan keinginan } \\
\text { orang lain }\end{array}$} & Memiliki toleransi & 7,8, & 28 & \multirow[t]{2}{*}{6} \\
\hline & & Menjaga perasaan orang lain & 13,14 & 27 & \\
\hline & \multirow{3}{*}{$\begin{array}{l}\text { Mampu memperbaiki } \\
\text { aspek kepribadian tidak } \\
\text { disenangi masyarakat }\end{array}$} & $\begin{array}{l}\text { Menerima nasehat } / \text { kritik dari } \\
\text { orang lain }\end{array}$ & 3,10 & 23 & \multirow[t]{3}{*}{5} \\
\hline & & Introspeksi diri & 17 & & \\
\hline & & $\begin{array}{l}\text { Mengubah perilaku yang } \\
\text { tidak disenangi masyarakat }\end{array}$ & 18 & & \\
\hline & Jumlah & & 19 & 9 & 28 \\
\hline
\end{tabular}


Penskoran disesuaikan dengan skala Likert yaitu pernyataan positif dan pernyataan negatif, sebagaimana dijelaskan pada Tabel 3.

Tabel 3. Pensekoran Instrumen

\begin{tabular}{|c|c|c|c|}
\hline \multicolumn{4}{|c|}{ Penskoran Jawaban Untuk Item Pertanyaan Positif } \\
\hline No & Jawaban & Skor & Keterangan \\
\hline 1 & $\mathrm{~A}$ & 5 & $\begin{array}{l}\text { Jawaban sangat memenuhi kriteria yang } \\
\text { diharapkan }\end{array}$ \\
\hline 2 & $\mathrm{~B}$ & 4 & Jawaban memenuhi kriteria yang diharapkan \\
\hline 3 & $\mathrm{C}$ & 3 & $\begin{array}{l}\text { Jawaban cukup memenuhi kriteria yang } \\
\text { diharapkan }\end{array}$ \\
\hline 4 & $\mathrm{D}$ & 2 & $\begin{array}{l}\text { Jawaban tidak memenuhi kriteria yang } \\
\text { diharapkan }\end{array}$ \\
\hline 5 & $\mathrm{E}$ & 1 & $\begin{array}{l}\text { Jawaban sangat tidak memenuhi kriteria yang } \\
\text { diharapkan }\end{array}$ \\
\hline \multicolumn{4}{|c|}{ Penskoran Jawaban Untuk Item Pertanyaan Negatif } \\
\hline No & Jawaban & Skor & Keterangan \\
\hline 1 & A & 1 & $\begin{array}{l}\text { Jawaban sangat tidak memenuhi kriteria yang } \\
\text { diharapkan }\end{array}$ \\
\hline 2 & $\mathrm{~B}$ & 2 & $\begin{array}{l}\text { Jawaban tidak memenuhi kriteria yang } \\
\text { diharapkan }\end{array}$ \\
\hline 3 & $\mathrm{C}$ & 3 & $\begin{array}{l}\text { Jawaban cukup memenuhi kriteria yang } \\
\text { diharapkan }\end{array}$ \\
\hline 4 & $\mathrm{D}$ & 4 & Jawaban memenuhi kriteria yang diharapkan \\
\hline 5 & $\mathrm{E}$ & 5 & $\begin{array}{l}\text { Jawaban sangat memenuhi kriteria yang } \\
\text { diharapkan }\end{array}$ \\
\hline
\end{tabular}

\section{Analisis Data}

Setelah data-data yang dibutuhkan terkumpul maka tahap selanjutnya dalam penelitian ini adalah analisis data. Ghozali dan Laten, (2015), menganalisa data dalam penelitian adalah untuk mencari signifikansi perbedaan antara tes sebelum perlakuan dan sesudah perlakuan yang menunjukan kuat lemahnya Efektivitas variabel $\mathrm{X}$ dalam mempengaruhi variabel Y, menggunakan rumus Paired Samples T-test sebagai berikut:

$t=\frac{\bar{M} d}{\sqrt{\frac{\sum x^{2} d}{N(N-1)}}}$

Keterangan:

$\bar{M} d=$ mean dari deviasi (d) antara posttest dan pretest

$x^{2} d=$ perbedaan deviasi dengan mean deviasi

$N \quad$ = banyaknya subyek

$d f=$ atau db adalah N-1 
Selanjutnya untuk proses analisis data yang lebih akurat dan efisien dalam perhitungannya, maka perhitungan analisis data akan dikerjakan dengan menggunakan program SPSS 20 for Windows.

\section{HASIL DAN PEMBAHASAN}

Proses intervensi terhadap subjek yang telah terjaring dilaksanakan selama 4 bulan, dimulai 6 Agustus 2018 dan berakhir pada 10 Desember 2018. Intervensi dilakukan oleh Peneliti yang berperan sebagai Konselor. Pretest diberikan di awal intervensi untuk mengetahui kriteria kecemasan berpendapat siswa sebelum pemberian intervensi. setelah itu diberikan Posttest. Berikut tabel siswa yang tergolong kecemasan mengemukakan pendapat tinggi berdasarkan pengukuran:

Tabel 3. Hasil Pretest Siswa yang Tergolong Konsep Diri Rendah

\begin{tabular}{llll}
\hline No & Responden & Skor & Kategori \\
\hline 1 & AA & 72 & Rendah \\
\hline 2 & BE & 78 & Rendah \\
\hline 3 & DVP & 75 & Rendah \\
\hline 4 & ERD & 73 & Rendah \\
\hline 5 & IDP & 77 & Rendah \\
\hline 6 & NPS & 77 & Rendah \\
\hline 7 & MH & 75 & Rendah \\
\hline 8 & ADM & 75 & Rendah \\
\hline 9 & DFA & 79 & Rendah \\
\hline 10 & IFA & 75 & Rendah \\
\hline 11 & MZ & 72 & Rendah \\
\hline 12 & NR & 77 & Rendah \\
\hline 13 & TCU & 75 & Rendah \\
\hline
\end{tabular}

Hasil perolehan skor pretest konsep diri positif siswa rendah tersebut secara jelas dalam grafik pada Gambar 4 .

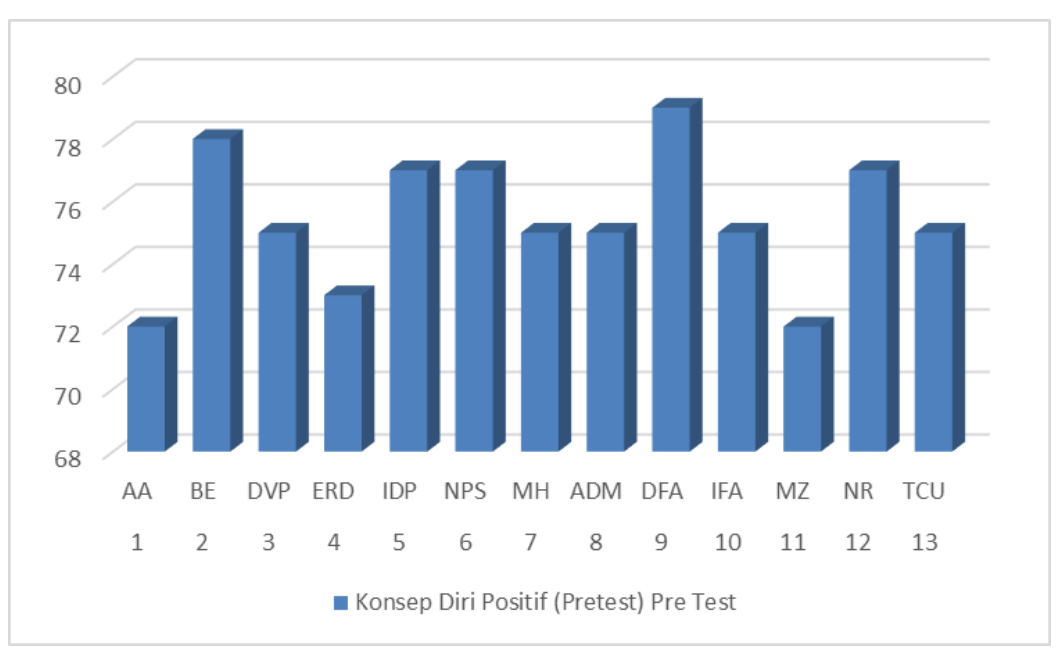

Gambar 4. Skor Pretest Konsep Diri Rendah 
Melihat kondisi tersebut maka 13 siswa yang tergolong konsep diri rendah diberikan konseling kelompok cognitive behavior dengan harapan akan terjadi perubahan yang signifikan. Proses pemberian konseling kelompok cognitive behavior ini dilakukan oleh peneliti. Pada awal konseling dilakukan pretest yang tujuan adalah untuk mengetahui tingkat konsep diri positif pada siswa, pretest ini diberikan sebelum konseling kelompok cognitive behavior. Setelah diadakan pretest maka akan diketahui tingkat konsep diri kemudian diberikan konseling kelompok cognitive behavior, setelah konseling kelompok cognitive behavior berakhir, maka akan diadakan postest yang tujuannya yaitu untuk mengetahui tingkat konsep diri dengan menggunakan angket konsep diri yang sama dengan pretest. Berikut hasil pemaparan skor pretest dan posttest setelah diberikan perlakuan konseling kelompok cognitive behavior:

Tabel 4. Hasil Pretest-Posttest

\begin{tabular}{llclclcl}
\hline No & Konseli & Pretest & Kriteria & Postest & Kriteria & Arah Perbedaan & Point \\
\hline 1 & AA & 72 & Rendah & 84 & Sedang & A1<A2 & 12 \\
\hline 2 & BE & 78 & Rendah & 87 & Sedang & A1<A2 & 9 \\
\hline 3 & DVP & 75 & Rendah & 86 & Sedang & A1<A2 & 11 \\
\hline 4 & ERD & 73 & Rendah & 87 & Sedang & A1<A2 & 14 \\
\hline 5 & IDP & 77 & Rendah & 84 & Sedang & A1<A2 & 7 \\
\hline 6 & NPS & 77 & Rendah & 88 & Tinggi & A1<A2 & 11 \\
\hline 7 & MH & 75 & Rendah & 87 & Sedang & A1<A2 & 12 \\
\hline 8 & ADM & 75 & Rendah & 83 & Rendah & A1<A2 & 8 \\
\hline 9 & DFA & 79 & Rendah & 85 & Sedang & A1<A2 & 6 \\
\hline 10 & IFA & 75 & Rendah & 85 & Sedang & A1<A2 & 10 \\
\hline 11 & MZ & 72 & Rendah & 86 & Sedang & A1<A2 & 14 \\
\hline 12 & NR & 77 & Rendah & 86 & Sedang & A1<A2 & 9 \\
\hline 13 & TCU & 75 & Rendah & 88 & Tinggi & A1<A2 & 13 \\
\hline
\end{tabular}

Adapun point frekuensi konsep diri positif siswa sebelum diberi konseling kelompok cognitive behavior dan konsep diri positif siswa sesudah diberi konseling kelompok cognitive behavior tersebut secara jelas tergambar dalam Gambar 5.

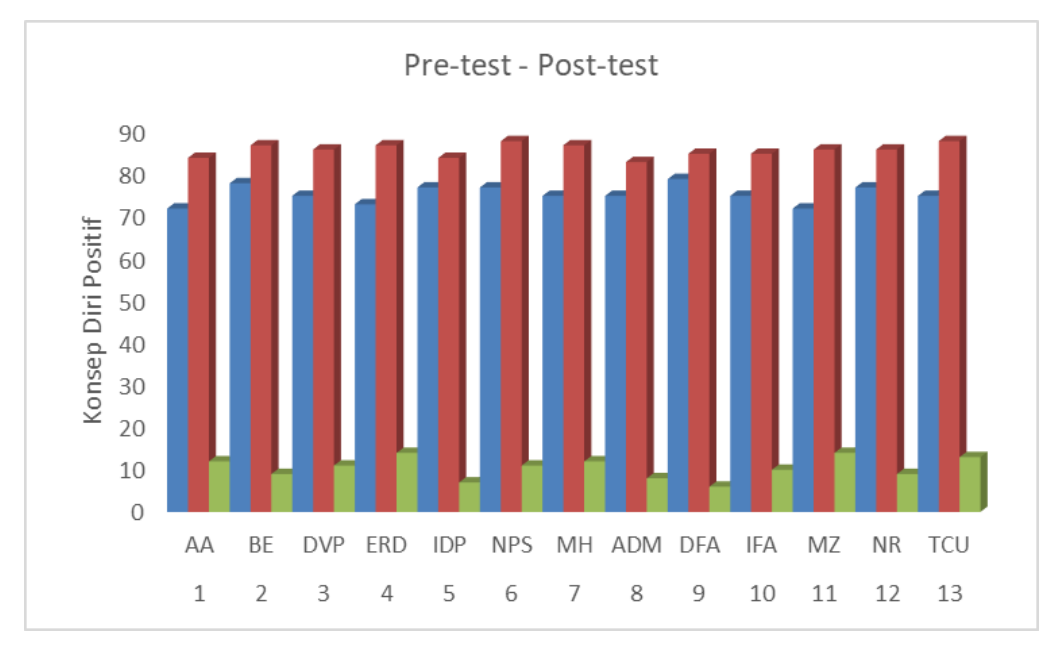

Gambar 5. Konsep Diri Positif Siswa Sebelum Dan Sesudah Diberi Konseling Kelompok Cognitive behavior (Pretest-Posttest) 
Pada Gambar 5 dapat disimpulkan bahwa skor posttest seluruh obyek mengalami peningkatan secara signifikan, apabila dibanding dengan skor pretest. Berikut adalah penjelasan peningkatan skor hasil pretest dan posttest dari responden.

Subjek $A A$

AA adalah siswa kelas VII-A. AA cenderung merasa tidak disenangi oleh orang lain. Ia merasa tidak diperhatikan, karena itulah ia bereaksi pada orang lain sebagai musuh, skor konsep diri positif AA sebelum mendapat perlakuan adalah 72 yang termasuk dalam kategori rendah. Skor konsep diri positif AA sesudah mendapat perlakuan adalah 84 yang termasuk dalam kategori sedang, Jadi terdapat kenaikan skor konsep diri positif sebanyak 12 poin.

\section{Subjek BE}

BE adalah siswa kelas VII-A, BE merasa tidak pandai dan tidak sanggup mengungkapkan penghargaan atau pengakuan pada kelebihan orang lain. Skor konsep diri positif BE sebelum mendapat perlakuan adalah 78 yang termasuk dalam kategori rendah Skor konsep diri positif BE sesudah mendapat perlakuan adalah 87 yang termasuk dalam kategori sedang. Jadi terdapat kenaikan skor konsep diri positif sebanyak 9 poin.

\section{Subjek DVP}

DVP adalah siswa kelas 7A, DVP cenderung merasa tidak disenangi oleh orang lain. Skor konsep diri positif DVP sebelum mendapat perlakuan adalah 75 yang termasuk dalam kategori rendah. Skor konsep diri positif DVP sesudah mendapat perlakuan adalah 86 yang termasuk dalam kategori sedang. Jadi terdapat kenaikan skor konsep diri positif sebanyak 11 poin.

\section{Subjek ERD}

ERD adalah siswa kelas 7A, ERD akan menganggap tidak akan berdaya melawan persaingan yang merugikan dirinya. Skor konsep diri positif ERD sebelum mendapat perlakuan adalah 73 yang termasuk dalam kategori rendah. Skor konsep diri positif ERD sesudah mendapat perlakuan adalah 87 yang termasuk dalam masih kategori sedang. Jadi terdapat kenaikan skor konsep diri positif sebanyak 14 poin.

Subjek IDP

IDP adalah siswa kelas 7A. IDP hyperkritis terhadap orang lain. Ia Iselalu mengeluh, mencelah atau meremehkan apapun atau siapapun. Skor konsep diri positif IDP sebelum mendapat perlakuan adalah 77 yang termasuk dalam kategori rendah. Skor konsep diri positif IDP sesudah mendapat perlakuan adalah 84 yang termasuk dalam kategori sedang. Jadi terdapat kenaikan skor konsep diri positif sebanyak 7 poin.

\section{Subjek NPS}

NPS adalah siswa kelas 7A, NPS tidak yakin akan cita-cita yang akan dicapainya kedepan, sehingga ketika harapan itu tidak terwujud, ia tidak mampu melihat sisi positif dirinya. Skor konsep diri positif NPS sebelum mendapat perlakuan adalah 77 yang termasuk dalam kategori rendah. Skor konsep diri positif NPS sesudah mendapat perlakuan adalah 88 yang termasuk dalam kategori tinggi. Jadi terdapat kenaikan skor konsep diri positif sebanyak 11 poin.

Subjek $\mathrm{NH}$

$\mathrm{NH}$ adalah siswa kelas 7A. NH Ia sering merasa tidak percaya akan kompetensi/kemampuan diri dalam hidup dilingkungan. Skor konsep diri positif $\mathrm{NH}$ 
sebelum mendapat perlakuan adalah 75 yang termasuk dalam kategori rendah. Skor konsep diri positif $\mathrm{NH}$ sesudah mendapat perlakuan adalah 87 yang termasuk dalam kategori sedang. Jadi terdapat kenaikan skor konsep diri positif sebanyak 12 poin.

\section{Subjek ADM}

ADM adalah siswa kelas 7B, ADM merasa rendah diri atau bahkan berperilaku yang tidak disenangi, misalkan membenci, me. Skor konsep diri positif ADM sebelum mendapat perlakuan adalah 75 yang termasuk dalam kategori rendah. Skor konsep diri positif ADM sesudah mendapat perlakuan adalah 83 yang termasuk dalam kategori sedang. Jadi terdapat kenaikan skor konsep diri positif sebanyak 8 poin.

\section{Subjek DFA}

DFA adalah siswa kelas 7B, DFA keengganannya untuk bersaing dengan orang lain dalam membuat prestasi. Skor konsep diri positif DFA sebelum mendapat perlakuan adalah 79 yang termasuk dalam kategori rendah. Skor konsep diri positif DFA sesudah mendapat perlakuan adalah 85 yang termasuk dalam kategori sedang. Jadi terdapat kenaikan skor konsep diri positif sebanyak 6 poin.

\section{Subjek IFA}

IFA adalah siswa kelas 7B, SN menganggap pada dirinya tidak akan berdaya melawan persaingan yang merugikan dirinya. Skor konsep diri positif IFA sebelum mendapat perlakuan adalah 75 yang termasuk dalam kategori rendah. Skor konsep diri positif IFA sesudah mendapat perlakuan adalah 85 yang termasuk dalam kategori sedang. Jadi terdapat kenaikan skor konsep diri positif sebanyak 10 poin.

\section{Subjek $M Z$}

MZ adalah siswa kelas 7B, MZ sering tidak tahan terhadap kritik yang diterimanya dan mudah marah atau naik pitam,. Skor konsep diri positif MZ sebelum mendapat perlakuan adalah 72 yang termasuk dalam kategori rendah. Skor konsep diri positif MZ sesudah mendapat perlakuan adalah 86 yang termasuk dalam kategori sedang. Jadi terdapat kenaikan skor konsep diri positif sebanyak 14 poin.

\section{Subjek NR}

NR adalah siswa kelas 7B, NR tidak mempunyai cara pandang yang positif terhadap diri sendiri,. Skor konsep diri positif NR sebelum mendapat perlakuan adalah 77 yang termasuk dalam kategori rendah. Skor konsep diri positif NR sesudah mendapat perlakuan adalah 86 yang termasuk dalam kategori sedang. Jadi terdapat kenaikan skor konsep diri positif sebanyak 9 poin.

\section{Subjek TCU}

TCU adalah siswa kelas 7B, TCU Ia tidak mampu untuk mengintrospeksi dirinya sendiri sebelum menginstrospeksi orang lain,Skor konsep diri positif TCU sebelum mendapat perlakuan adalah 75 yang termasuk dalam kategori rendah. Skor konsep diri positif TCU sesudah mendapat perlakuan adalah 88 yang termasuk dalam kategori tinggi. Jadi terdapat kenaikan skor konsep diri positif sebanyak 13 poin.

\section{Pengujian Hipotesis}

Berdasarkan rumusan masalah yang diajukan, maka terdapat Hipotesis yang harus diuji dalam penelitian adalah: 
Ha : Konseling kelompok cognitive behavior efektif untuk meningkatkan pemahaman konsep diri positif siswa SMP

Ho : Konseling kelompok cognitive behavior tidak efektif untuk meningkatkan pemahaman konsep diri positif siswa SMP

Untuk mengidentifikasi ada tidaknya serta efektivitas konseling kelompok realita untuk meningkatkan pemahaman identitas diri siswa SMP, penulis menggunakan analisa data kuantitatif. Adapun rumus yang digunakan adalah rumus T-test. Selanjutnya penghitungan dilakukan dengan bantuan komputer program SPSS 20 for windows. T-tes adalah rumus yang digunakan khusus dalam menguji hipotesis yang berisi tentang sifat dan kemampuan (traits and ability). Adapun uji t yang digunakan adalah Paired-sample Ttest. Untuk melihat harga $\mathrm{t}$ tabel maka didasarkan pada derajat kebebasan (dk), yaitu besarnya adalah $\mathrm{N}-1$, yaitu 13-1=12 dan pada taraf signifikan $\alpha=0,05(95 \%)$ maka didapatkan t-tabel $=1.782$, dengan asumsi jika t-hitung > t-tabel maka Ha "diterima"

Berdasarkan hasil analisis uji $\mathrm{t}$ dua sampel berpasangan pada tabel 4.8, sehingga dapat diperoleh hasil sebagai berikut: nilai t-hitung lebih besar dari t-tabel $(7.597>1.782)$. Karena nilai t-hitung $>\mathrm{t}$-tabel, maka hipotesis yang diajukan berupa hipotesis alternatif (Ha) yang berbunyi terdapat keefektifan konseling kelompok cognitive behavior untuk meningkatkan konsep diri positif siswa SMP "diterima". Selanjutnya dari tabel 5, tersebut pula dapat diketahui bahwa nilai $t$ bertanda positif, ini mempunyai arti bahwa variabel bebas (konseling kelompok cognitive behavior) mempunyai pengaruh yang signifikan dalam mempengaruhi variabel terikat (konsep diri positif).

\section{Pembahasan}

Konsep diri positif merupakan cara pandang secara menyeluruh tentang dirinya, yang meliputi kemampuan yang dimiliki, perasaan yang dialami, kondisi fisik dirinya maupun lingkungan terdekatnya, konsep diri positif merupakan penentu sikap individu dalam bertingkah laku, artinya apabila individu cenderung berpikir akan berhasil, maka hal ini merupakan kekuatan atau dorongan yang akan membuat individu menuju kesuksesan. Sebaliknya jika individu berpikir akan gagal, maka hal ini sama saja mempersiapkan kegagalan bagi dirinya. Individu yang memiliki konsep diri positif dapat menanggapi segala sesuatu secara positif, dapat memahami dan menerima sejumlah fakta yang sangat bermacam-macam tentang dirinya sendiri. Ia akan percaya diri, akan bersikap yakin dalam bertindak dan berperilaku, Sedangkan individu yang memiliki konsep diri negatif akan menanggapi segala sesuatu dengan pandangan negatif pula, dia akan mengubah terus menerus konsep dirinya atau melindungi konsep dirinya itu secara kokoh dengan cara mengubah atau menolak informasi baru dari lingkungannya.

Dapat diketahui bahwa sebanyak 13 responden $(24,29 \%)$ memiliki skor dibawah rata-rata dari skor konsep diri positif. Sedangkan 46 responden $(69,70 \%)$ memiliki skor sama dengan rata-rata dan sebanyak 6 responden $(9,09 \%)$ memiliki skor di atas rata-rata dari skor konsep diri positif sebelum konseling kelompok cognitive behavior. Dengan demikian dapat disimpulkan bahwa konsep diri positif sebelum diberi konseling kelompok cognitive behavior termasuk kategori "sedang" karena banyak responden yang memiliki skor diatas rata-rata (mean), meskipun masih ditemukan 13 responden yang memiliki konsep diri positif dalam kategori rendah. 
Sesuai dengan fungsi dan tujuan eksistensi layanan bimbingan dan konseling terutama konseling kelompok cognitive behavior yaitu sebagai aternatif bantuan untuk meningkatkan konsep diri positif siswa, maka 13 siswa yang tergolong rendah konsep diri positifnya diberikan konseling kelompok cognitive behavior dan dengan adanya perlakuan ini, diharapkan terjadi perubahan pada konsep diri positif rendah yang mereka miliki menuju perubahan yang lebih baik, diantara ciri-ciri konsep diri positif yang dijadikan indikator sebagai berikut: Indikatornya diantarnya: 1) Yakin akan kemampuan dalam mengatasi masalah, 2) Merasa setara dengan orang lain, 3) Menerima pujian tanpa rasa malu, 3) Kesadaran akan perasaan dan keinginan orang lain, 4) Mampu memperbaiki aspek kepribadian tidak disenangi masyarakat.

Hal sesuai yang diungkapkan Burns (2008, p. 50) yang mengatakan bahwa konsep diri positif adalah merupakan "pandangan menyeluruh individu tentang totalitas dari diri sendiri mengenai karakteristik kepribadian, nilai-nilai kehidupan, prinsip kehidupan, moralitas, kelemahan dan segala yang terbentuk dari segala pengalaman dan interaksinya dengan orang lain". Hal senada Suryabrata (2012) memberikan pengertian tentang konsep diri positif sebagai gambaran yang dimiliki orang tentang dirinya. Konsep diri positif ini merupakan gabungan dari keyakinan yang dimiliki individu tentang mereka sendiri yang meliputi karakteristik fisik, psikologis, sosial, emosional, aspirasi dan prestasi.

Berdasarkan hasil analisis uji $t$ dua sampel berpasangan a dapat diperoleh hasil: $t$ hitung lebih besar dari t-tabel $(7.597>1.782)$. Karena nilai t-hitung $>$ t-tabel, maka hipotesis yang penulis ajukan berupa hipotesis alternatif $(\mathrm{Ha})$ yang berbunyi terdapat keefektifan konseling kelompok cognitive behavior untuk meningkatkan konsep diri positif siswa SMP "diterima". Selanjutnya dari tabel 5 , tersebut pula dapat diketahui bahwa nilai t bertanda positif, ini mempunyai arti bahwa variabel bebas (konseling kelompok cognitive behavior) mempunyai pengaruh yang signifikan dalam mempengaruhi variabel terikat (konsep diri positif). Artinya jika variabel konseling kelompok cognitive behavior $(\mathrm{X})$ meningkatkan konsep diri positif secara efektif.

Hasil penelitian ini mendukung hasil penelitian sebelumnya yang dilakukan oleh Megalia (2016), dalam mengkaji pengaruh konseling cognitive behavior untuk mengurangi perilaku agresif, menemukan bahwa konseling cognitive behavior berpengaruh signifikan dalam mengurangi perilaku agresif siswa, hal ini dibuktikan bahwa hasil penelitianya yang dengan menggunakan kuesioner perilaku agresif pretest dan posttest, dan dianalisis dengan teknik analisis T-tes. Dari analisis dihasilkan bahwa perilaku agresif siswa sebelum diberi konseling cognitive behavior dalam kategori "Tinggi". Sedangkan perilaku agresif siswa sesudah diberi konseling cognitive behavior adalah dalam kategori "Rendah". Sedangkan hasil penelitian terakhir menunjukkan bahwa konseling individual efektif dalam mengurngi perilaku agresif siswa diterima karena thitung $>$ ttabel $(4,790>1,697)$.

Sedangkan penelitian yang lain yang dilakukan oleh Rusita (2014), dalam penelitianya pengaruh konseling kelompok terhadap konsep diri positif menemukan mengatakan bahwa variabel bebas yakni konseling kelompok berpengaruh berpengaruh variabel terikat (konsep diri positif).. Hal ini dibuktikan Dari analisis dihasilkan bahwa konseling kelompok dalam kategori "cukup baik". Hal ini dibuktikan dengan tanggapan 18 responden $(42,86 \%)$ memiliki skor di bawah rata-rata, 7 responden $(16,67 \%)$ memeiliki skor sama dengan rata-rata dan 17 responden $(40,48 \%)$ memiliki skor diatas rata-rata. Adapun dalam kategori "cukup baik". Kesimpulan ini dibuktikan dengan adanya konsep diri positif dengan 20 responden $(47,61 \%)$ memiliki skor di bawah rata-rata, 3 responden 
(7,14\%) memiliki skor rata-rata dan 19 responden $(45,23 \%)$ memiliki skor di bawah ratarata. Sedangkan hasil penelitian terakhir menyatakan bahwa konseling kelompok berpengaruh positif signifikan terhadap konsep diri positif. Hal tersebut dibuktikan dengan nilai r-hitung $(0,632)>$ r-tabel $(0,304)$ pada taraf signifikasi $\alpha=0,05$. Dengan demikian disimpulkan bahwa hipotesis alternatif (Ha) I yang penulis ajukan berbunyi "ada pengaruh konseling kelompok terhadap konsep diri positif terbukti kebenarannya, atau "diterima". Adapun besarnya pengaruh bimbingan keluarga terhadap konsep diri positif adalah lebih kecil dari 0,50 (50\%) yakni sebesar 0,400 (40\%), ini artinya hipotesis (Ha) II yang penulis ajukan juga terbukti kebenarannya, atau "diterima".

Kelebihan penelitian konseling kelompok cognitive behavior dapat meningkatkan konsep diri positif siswa SMP, hal tersebut dapat diketahui bahwa hasil penelitian bahwa t-hitung lebih besar dari t-tabel dan nilai $\mathrm{t}$ bertanda positif, ini mempunyai arti bahwa variabel bebas (konseling kelompok cognitive behavior) efektif dalam meningktkan variabel terikat (konsep diri positif). Artinya jika variabel konseling kelompok realita ditingkatkan maka akan berdampak untuk meningkatkan pemahaman identitas diri.

Sedangkan kekurangan penelitian ini hanya dilaksanakan pada siswa-siswi kelas VII SMPN 1 Kutorejo dan dilaksanakan pada semester genap tahun pelajaran 2018/2019, oleh karena itu perlu diujicobakan pada kelas lain atau jenjang pendidikan lainya.

\section{SIMPULAN}

Temuan penelitian menunjukkan bahwa konsep diri positif siswa SMP, sebelum pemberian konseling kelompok cognitive behavior termasuk dalam kategori sedang, meskipun masih ada beberapa responden yang memiliki konsep diri positif dalam kategori rendah. Artinya konsep diri positif yang dimiliki oleh siswa adalah bervariasi, sehingga perlu adanya deteksi sedini mungkin. Siswa yang memiliki konsep diri positif rendah, perlu mendapat layanan secara tepat, terprogram dan terpadu sesuai dengan karakteristik masing-masing siswa, sehingga memberi peluang terjadinya perubahan konsep diri negatif menjadi konsep diri positif. Temuan penelitian menunjukkan adanya perubahan dari konsep diri positif yang sedang menjadi baik pada siswa SMP, sesudah pemberian konseling kelompok cognitive behavior. Hal ini mengindikasikan bahwa perkembangan konsep diri positif pada siswa dapat mengalami perubahan dari waktu ke waktu Adanya keefektifan pemberian konseling kelompok cognitive behavior untuk meningkatkan konsep diri positif siswa SMP, memberi arti bahwa konseling kelompok cognitive behavior yang tepat dan sesuai dengan karakter siswa akan mampu menghantarkan perubahan yang berarti dalam perkembangan konsep diri positif siswa.

\section{REFERENSI}

Armeliza, V. (2013). Gambaran konsep diri remaja di lembaga permasyarakatan. (Skripsi tidak diterbitkan). Universitas Riau, Indonesia.

Ferrando, M., Prieto, M. D., Almeida, L. S., Ferrándiz, C., Bermejo, R., López-Pina, J. A., ... \& Fernández, M. C. (2011). Trait emotional intelligence and academic performance: Controlling for the effects of IQ, personality, and self-concept. Journal of Psychoeducational Assessment, 29(2), 150-159. 
Ghozali, I., \& Latan, H. (2015). Partial least squares: Konsep, teknik dan aplikasi menggunakan program SmartPLS 3.0 untuk penelitian empiris. Semarang: Badan Penerbit UNDIP.

Habsy, B. A. (2017a). Model konseling kelompok cognitive behavior untuk meningkatkan self esteem siswa SMK. Perspektif Ilmu Pendidikan, 31(1), 21-35. doi: 10.21009/PIP.311.4

Habsy, B. A. (2017b). Filosofi ilmu bimbingan dan konseling Indonesia. Jurnal Pendidikan (Teori dan Praktik), 2(1), 1-11. doi: 10.26740/jp.v2n1.p1-11

Habsy, B. A. (2017c). Seni memehami penelitian kualitatif dalam bimbingan dan konseling: Studi literatur. Jurnal Konseling Andi Matappa, 1(2), 90-100. doi: http://dx.doi.org/10.31100/jurkam.v1i2.56

Habsy, B. A. (2018). Model Bimbingan Kelompok PPPM Untuk Mengembangkan Pikiran Rasional Korban Bullying Siswa SMK Etnis Jawa. Jurnal Pendidikan (Teori dan Praktik), 2(2), 91-99. doi: 10.26740/jp.v2n2.p91-99

Habsy, B. A., Hidayah, N., Lasan, B. B., \& Muslihati, M. (2017). A literature review of indonesian life concept linuwih based on the teachings of adiluhung Raden Mas Panji Sosrokartono. In 3rd International Conference on Education and Training (ICET 2017). Atlantis Press.

Mulyana, D. (2011). Komunikasi kontekstual. Bandung: Remaja Rosdakarya.

Putri, D. R., Rudibyani, R. B., \& Sofya, E. (2017). Pembelajaran Discovery Learning untuk Meningkatkan Efikasi Diri dan Penguasaan Konsep Siswa. Jurnal Pendidikan dan Pembelajaran Kimia, 6(2), 296-307.

Pramono, A. (2013). Pengembangan Model Bimbingan Kelompok Melalui Teknik Psikodrama untuk Mengembangkan Konsep diri Positif. Jurnal Bimbingan Konseling, 2(2), 99-104.

Rakhmat, J., \& Komunikasi, P. (2005). Bandung: Remaja Rosdakarya

Rogers, M. E., \& Creed, P. A. (2011). A longitudinal examination of adolescent career planning and exploration using a social cognitive career theory framework. Journal of adolescence, $34(1), 163-172$.

Surya, M. (2012). Peluang dan tantangan globalisasi profesi bimbingan dan konseling. Dımensi Pendidikan, 1(2), 1-7.

Sa'adah, F. M., \& Rahman, I. K. (2015). Konsep bimbingan dan konseling cognitive behavior therapy (CBT) dengan pendekatan Islam untuk meningkatkan sikap altruisme siswa. HISBAH: Jurnal Bimbingan Konseling dan Dakwah Islam, 12(2), 49-59.

Wylie, R. C. (1974). The self-concept: Theory and research on selected topics (Vol. 2). Nebraska: University of Nebraska Press. 